\section{Physiological Response of 'TifEagle' Bermudagrass to Paclobutrazol}

\author{
Patrick E. McCullough, ${ }^{1}$ Haibo Liu, ${ }^{2}$ Lambert B. McCarty, ${ }^{3}$ and \\ Ted Whitwell ${ }^{3}$ \\ Department of Horticulture, Clemson University, Clemson, SC 29634-0375
}

Additional index words. plant growth regulator, PGR

\begin{abstract}
Research was conducted in two studies at the Clemson University Greenhouse Complex, Clemson, S.C., with the objective of evaluating 'TifEagle' bermudagrass (Cynodon dactylon $\times$ C. transvaalensis) response to paclobutrazol. TifEagle bermudagrass plugs were placed in $40 \mathrm{~cm}$ polyvinylchloride containers, with $20.3-\mathrm{cm}$-diameters and built to U.S. Golf Association specifications with 85 sand : 15 peatmoss (by volume) rootzone mix. Paclobutrazol was applied to separate containers at $0,0.14,0.28$, and $0.42 \mathrm{~kg}^{\circ} \mathrm{ha}^{-1}$ (a.i.) per 6 weeks. Minor phytotoxicity occurred with $0.14 \mathrm{~kg} \cdot \mathrm{ha}^{-1}$ applications, but turf quality was unaffected. Severe bermudagrass phytotoxicity occurred from paclobutrazol at 0.28 and $0.42 \mathrm{~kg} \cdot \mathrm{ha}^{-1}$. Total clipping yield from 12 sampling dates was reduced $65 \%, 84 \%$, and $92 \%$ from $0.14,0.28$, and $0.42 \mathrm{~kg} \cdot \mathrm{ha}^{-1}$, respectively. Root mass after 12 weeks was reduced $28 \%$, $45 \%$, and $61 \%$ for turf treated $0.14,0.28$, and $0.42 \mathrm{~kg} \cdot \mathrm{ha}^{-1}$, respectively. Paclobutrazol reduced root length $13 \%, 19 \%$, and $19 \%$ by $0.14,0.28$, and $0.42 \mathrm{~kg}^{\circ} \mathrm{ha}^{-1}$, respectively. Turf discoloration and negative rooting responses advocate caution when using paclobutrazol on 'TifEagle' bermudagrass. Chemical names used: (+/-)-( $\left.\mathbf{R}^{*}, \mathbf{R}^{*}\right)-\mathbf{B}-[(\mathbf{4}-$ chlorophenyl) methyl]-alpha-( 1, 1-dimethyl)-1H-1,2,4,-triazole-1-ethanol (paclobutrazol).
\end{abstract}

Growth inhibition with plant growth regulators (PGRs) has become an important practice in turfgrass management (Watcshke et al., 1992). PGRs modify turfgrass growth by inhibiting either cell division or cell elongation (Hedden and Hoad, 1994). Phytotoxicity and root reductions have prevented widespread use of cell division inhibitors, therefore, gibberellic acid (GA) inhibitors are more frequently used due to less likelihood for leaf burn and turfgrass injury (Murphy et al., 2001).

A popular PGR in golf course management, paclobutrazol, inhibits the conversion of ent-kaurene to ent-kaurenoic acid early in the GA biosynthesis pathway (Fletcher et al., 2000). Paclobutrazol inhibits plant growth by blocking the enzyme ent-kaurene oxidase which is responsible for the oxidation of ent-kaurene, ent-kaurenol, and ent-kaurenal from forming GA $_{12}$-aldehyde(Sponsel, 1995; Buchanan etal., 2000). Inhibition of ent-kaurene oxidase may decrease cell number, reduce cortical cells, and reduce xylem length (Fletcher et al., 2000a).

Additionally, heterocyclic nitrogen atoms of paclobutrazol may bind to the protoheme iron atom in cytochrome P-450 systems resulting in the inhibition of gibberellins and the activity of P-450 mono-oxygenase enzymes involved in brassinosteroid synthesis (Fletcher et al., 2000). In isolated wheat mitochondria, paclobutrazol altered electron transport during the final stage of respiration, presenting another possible mode of action (Bai and Chaney, 2001).

Existing concerns with paclobutrazol ap-

Received for publication 16 Dec. 2003. Accepted for publication 20 May 2004. Contribution from the South Carolina Agricultural Experiment Station. ${ }^{1}$ Graduate assistant.

${ }^{2}$ Associate professor. To whom reprint requests should be addressed; e-mail haibol@clemson.edu. ${ }^{3}$ Professor. plications include turfgrass discoloration and root growth inhibition. Over a two year period, Fagerness and Yelverton (2001) noted creeping bentgrass (Agrostis palustris Huds.) root growth was not affected by monthly applications of paclobutrazol at 0.14 and $0.28 \mathrm{~kg} \cdot \mathrm{ha}^{-1}$. Only paclobutrazol applied at twice the labeled rate of $0.56 \mathrm{~kg} \cdot \mathrm{ha}^{-1}$ inhibited root growth.

Paclobutrazol is also an effective PGR for common (Cynodon dactylon) and 'Tifway' bermudagrass (Johnson, 1990). Suppression of 'Tifway' bermudagrass growth with paclobutrazol was comparable after initial applications to flurprimidol \{alpha-(1-methylethyl)-alpha-[4-(trifluoro-methoxy) phenyl] 5-pyrimidine-methanol \}, a similar PGR compound, at $0.84 \mathrm{~kg} \cdot \mathrm{ha}^{-1}$ (a.i.) (Johnson, 1992).

Although paclobutrazol has tested successfully on hybrid bermudagrass maintained at higher mowing heights, applications on dwarftype bermudagrass putting greens have not been reported. Dwarf bermudagrass tolerates long-term routine close mowing heights of $3.2 \mathrm{~mm}$ or closer (McCarty and Miller, 2002). However, with potentially reduced photosynthetic capacity, the close mowing endurance of cultivars like 'TifEagle' has apparently been at the expense of vigorous root systems (White, 1998). With the popularity of PGR applications on golf course turf, shoot growth restrictions followed by root growth inhibition could limit the use of PGRs like paclobutrazol on dwarf bermudagrass turf.

The objective of this greenhouse experiment was to assess the response of 'TifEagle' bermudagrass to repeat applications of paclobutrazol over 3 months.

\section{Materials and Methods}

Research was conducted in two studies (denoted Study 1 and Study 2) at the Clemson University Greenhouse, Clemson, S.C., from
December to May 2003. Greenhouse day/night temperatures were set for about $24 / 19{ }^{\circ} \mathrm{C}$. To reduce greenhouse variability from reduced natural light during winter months, the experimental design was a randomized complete block with four replications for Study 1 and three replications for Study 2. Plugs were collected from a 'TifEagle' bermudagrass green located in the Turf Service Center, Clemson, S.C. Soil was washed and plugs were placed in polyvinylchloride containers with 40-cm depths and $324-\mathrm{cm}^{2}$ surface areas built approximately to USGA specification (USGA Green Section Staff, 1993). The soil medium was a mediumto coarse-textured rootzone mix of 85 sand : 15 peatmoss (by volume). A starter fertilizer $\left(9 \mathrm{~N}-18 \mathrm{P}_{2} \mathrm{O}_{5}-17 \mathrm{~K}_{2} \mathrm{O}\right.$ HP Starter Fertilizer; Scott's Co., Marysville, Ohio) was mixed into the soil with $\mathrm{N}$ at $48 \mathrm{~kg} \cdot \mathrm{ha}^{-1}$. Nitrogen sources included $6.3 \%$ ammoniacal $\mathrm{N}, 0.5 \%$ urea $\mathrm{N}$, $1.1 \%$ methylenediurea and dimethylenetriurea, and $1.1 \%$ water insoluble N. Supplemental lighting was provided daily at about $50 \mu \mathrm{mol} \cdot \mathrm{m}^{2} \cdot \mathrm{s}^{-1}$ for $4 \mathrm{hin}$ December and January, $3 \mathrm{~h}$ in February, $2 \mathrm{~h}$ in March, and $1 \mathrm{~h}$ in April.

Turf was irrigated and maintained daily at a 4-mm mowing height and allowed a 1 month establishment period. Weekly nitrogen (N) applications were made with an ammonium nitrate solution at $6 \mathrm{~kg} \cdot \mathrm{ha}^{-1}$. Two weeks before initial treatments, a 16-4-8 (urea N) fertilizer (Pendleton Oil Mill Fertilizer, Pendleton, S.C.) with complete micronutrients was applied at 24 $\mathrm{kg} \cdot \mathrm{ha}^{-1}$. Paclobutrazol was applied at $0,0.14$, 0.28 , or $0.42 \mathrm{~kg} \cdot \mathrm{ha}^{-1}$ (a.i.) per 6 weeks (Table 1) with a greenhouse spray cabinet (model SB6-094; Devries Manufacturing, Hollandale, Minn.) with a 6-hp (model 919.165110; Craftsman) pump delivering $560 \mathrm{~L} \cdot \mathrm{ha}^{-1}$ with a single $8002 \mathrm{E}$ nozzle at $170 \mathrm{kPa}$.

Visual quality ratings were made on a 1 to 9 scale with $9=$ dark green turf and $1=$ completely dormant turf. Quality ratings below 7 were considered unacceptable. Phytotoxicity was rated on a 0 to 5 scale with $5=$ completely dead or dormant turf. Phytotoxicity ratings $\geq 1$ were considered unacceptable. Clippings were harvested weekly, oven-dried at $100{ }^{\circ} \mathrm{C}$ for $48 \mathrm{~h}$, then weighed. After 12 weeks, roots and thatch were sampled from the entire container, oven-dried at $100{ }^{\circ} \mathrm{C}$ for $48 \mathrm{~h}$, and then weighed. Chlorophyll concentrations ( $\mathrm{mg} \mathrm{g}^{-1}$ of fresh clipping weight) were determined 4 , 8 , and 12 weeks after initial treatments with a spectrophotometer (Genesys 20 Thermo Spectronic model 4001/4, Waltham, Mass.). Light absorbance was measured at $663 \mathrm{~nm}$ for chlorophyll A and $645 \mathrm{~nm}$ for chlorophyll B. Procedures for chlorophyll concentration analysis were similar to those described by Moran and Porath (1980).

Table 1. Rates of paclobutrazol applied every 6 weeks to 'TifEagle' bermudagrass in two greenhouse experiments.

\begin{tabular}{|c|c|}
\hline Paclobutrazol & $\begin{array}{c}\text { Rate } \\
\left(\mathrm{kg} \cdot \mathrm{ha}^{-1} \text { per } 6 \text { weeks }\right)\end{array}$ \\
\hline$\overline{0}$ & --- \\
\hline 0.14 & 1 \\
\hline 0.28 & 2 \\
\hline 0.42 & 3 \\
\hline
\end{tabular}


Table 2. Turf quality for 'TifEagle' bermudagrass treated with repeat paclobutrazol applications at 6-week intervals. Different letters indicate a significantdifference at $P=0.05$ according to Fishers protected LSD test.

\begin{tabular}{|c|c|c|c|c|c|c|}
\hline \multirow{2}{*}{$\begin{array}{l}\text { Paclobutrazol } \\
\left(\mathrm{kg} \cdot \mathrm{ha}^{-1} \text { per } 6 \text { weeks }\right)\end{array}$} & \multicolumn{6}{|c|}{ Turf quality $^{\mathrm{z}}\left(\right.$ WAIT $\left.^{\mathrm{y}}\right)$} \\
\hline & 2 & 4 & 6 & 8 & 10 & 12 \\
\hline \multicolumn{7}{|l|}{ Study 1} \\
\hline 0 & $7.0 \mathrm{a}$ & $7.0 \mathrm{ab}$ & $7.0 \mathrm{ab}$ & $7.0 \mathrm{ab}$ & $7.0 \mathrm{ab}$ & $7.0 \mathrm{a}$ \\
\hline 0.14 & $7.0 \mathrm{a}$ & $7.8 \mathrm{a}$ & $7.5 \mathrm{a}$ & $8.0 \mathrm{a}$ & $7.5 \mathrm{a}$ & $7.8 \mathrm{a}$ \\
\hline 0.28 & $7.3 \mathrm{a}$ & $6.3 \mathrm{bc}$ & $6.3 \mathrm{~b}$ & $6.5 \mathrm{~b}$ & $6.0 \mathrm{~b}$ & $5.3 \mathrm{~b}$ \\
\hline 0.42 & $7.5 \mathrm{a}$ & $5.8 \mathrm{c}$ & $4.8 \mathrm{c}$ & $4.0 \mathrm{c}$ & $3.8 \mathrm{c}$ & $4.0 \mathrm{~b}$ \\
\hline \multicolumn{7}{|l|}{ Study 2} \\
\hline 0 & $7.0 \mathrm{~b}$ & $7.0 \mathrm{a}$ & $7.0 \mathrm{a}$ & $6.7 \mathrm{ab}$ & $7.0 \mathrm{a}$ & $6.7 \mathrm{a}$ \\
\hline 0.14 & $8.0 \mathrm{a}$ & $7.3 \mathrm{a}$ & $7.3 \mathrm{a}$ & $7.0 \mathrm{a}$ & $8.0 \mathrm{a}$ & $7.3 \mathrm{a}$ \\
\hline 0.28 & $8.0 \mathrm{a}$ & $7.3 \mathrm{a}$ & $7.3 \mathrm{a}$ & $7.7 \mathrm{a}$ & $7.0 \mathrm{a}$ & $5.7 \mathrm{~b}$ \\
\hline 0.42 & $8.0 \mathrm{a}$ & $7.0 \mathrm{a}$ & $5.7 \mathrm{a}$ & $5.7 \mathrm{~b}$ & $5.7 \mathrm{~b}$ & $5.0 \mathrm{~b}$ \\
\hline
\end{tabular}

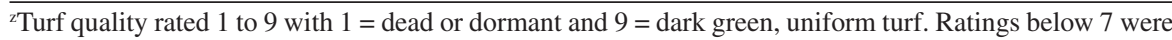
considered unacceptable.

${ }^{\mathrm{y}} \mathrm{WAIT}=$ week after initial treatments.

Table 3. Phytotoxicity for 'TifEagle' bermudagrass treated with repeat paclobutrazol applications at 6-week intervals. Different letters indicate a significantdifference at $P=0.05$ according to Fishers protected LSD test.

\begin{tabular}{|c|c|c|c|c|c|c|}
\hline \multirow{2}{*}{$\begin{array}{l}\text { Paclobutrazol } \\
\left(\mathrm{kg} \cdot \mathrm{ha}^{-1} \text { per } 6 \text { weeks }\right)\end{array}$} & \multicolumn{6}{|c|}{ Phytotoxicity $^{\mathrm{z}}\left(\right.$ WAIT $\left.^{\mathrm{y}}\right)$} \\
\hline & 2 & 4 & 6 & 8 & 10 & 12 \\
\hline \multicolumn{7}{|l|}{ Study 1} \\
\hline 0 & $0.0 \mathrm{c}$ & $0.0 \mathrm{~d}$ & $0.0 \mathrm{c}$ & $0.0 \mathrm{c}$ & $0.0 \mathrm{~d}$ & $0.0 \mathrm{~d}$ \\
\hline 0.14 & $0.5 \mathrm{bc}$ & $1.5 \mathrm{c}$ & $0.0 \mathrm{c}$ & $0.3 \mathrm{c}$ & $1.5 \mathrm{c}$ & $1.5 \mathrm{c}$ \\
\hline 0.28 & $1.5 \mathrm{ab}$ & $2.8 \mathrm{~b}$ & $1.5 \mathrm{~b}$ & $1.5 \mathrm{~b}$ & $2.8 \mathrm{~b}$ & $2.8 \mathrm{~b}$ \\
\hline 0.42 & $2.5 \mathrm{a}$ & $3.8 \mathrm{a}$ & $3.3 \mathrm{a}$ & $3.5 \mathrm{a}$ & $4.0 \mathrm{a}$ & $4.0 \mathrm{a}$ \\
\hline \multicolumn{7}{|l|}{ Study 2} \\
\hline 0 & $0.0 \mathrm{a}$ & $0.0 \mathrm{c}$ & $0.0 \mathrm{c}$ & $0.0 \mathrm{c}$ & $0.0 \mathrm{c}$ & $0.0 \mathrm{c}$ \\
\hline 0.14 & $0.0 \mathrm{a}$ & $0.7 \mathrm{bc}$ & $0.3 \mathrm{c}$ & $1.3 \mathrm{~b}$ & $1.3 \mathrm{~b}$ & $1.3 \mathrm{~b}$ \\
\hline 0.28 & $0.0 \mathrm{a}$ & $1.0 \mathrm{ab}$ & $1.3 \mathrm{~b}$ & $2.0 \mathrm{~b}$ & $2.0 \mathrm{~b}$ & $3.0 \mathrm{a}$ \\
\hline 0.42 & $0.0 \mathrm{a}$ & $1.7 \mathrm{a}$ & $2.3 \mathrm{a}$ & $3.7 \mathrm{a}$ & $3.7 \mathrm{a}$ & $3.3 \mathrm{a}$ \\
\hline
\end{tabular}

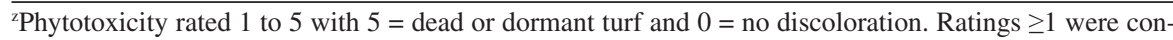
sidered unacceptable.

${ }^{\mathrm{y}} \mathrm{WAIT}=$ week after initial treatments.

Table 4. Total clipping yield, dry root mass, and root length for 'TifEagle' bermudagrass treated with repeat paclobutrazol applications at $0,0.14,0.28$, and $0.42 \mathrm{~kg} \cdot \mathrm{ha}^{-1}$ at 6 -week intervals. Different letters indicate a significant difference at $P=0.05$ for clipping yield and $P=0.10$ for root mass and length according to Fishers protected LSD test.

\begin{tabular}{lccc}
\hline $\begin{array}{l}\text { Paclobutrazol } \\
\left(\mathrm{kg} \cdot \mathrm{ha}^{-1} \text { per 6 weeks }\right)\end{array}$ & $\begin{array}{c}\text { Total clipping yield } \\
\left(\mathrm{g} \cdot \mathrm{m}^{-2}\right)\end{array}$ & $\begin{array}{c}\text { Dry root mass } \\
\left(\mathrm{g} \cdot \mathrm{m}^{-2}\right)\end{array}$ & $\begin{array}{c}\text { Root length }^{\mathrm{y}} \\
(\mathrm{cm})\end{array}$ \\
\hline 0 & $18.5 \mathrm{a}$ & $30.1 \mathrm{a}$ & $22.7 \mathrm{a}$ \\
0.14 & $6.5 \mathrm{~b}$ & $21.7 \mathrm{~b}$ & $19.7 \mathrm{~b}$ \\
0.28 & $3.0 \mathrm{c}$ & $16.7 \mathrm{bc}$ & $18.3 \mathrm{~b}$ \\
0.42 & $1.4 \mathrm{~d}$ & $11.7 \mathrm{c}$ & $18.3 \mathrm{~b}$ \\
$P$ value & & & 0.0063 \\
$\quad$ Linear & 0.0001 & 0.0007 & $\mathrm{NS}$ \\
$\quad$ Quadratic & 0.0001 & $\mathrm{NS}$ & $\mathrm{C}$ \\
\hline
\end{tabular}

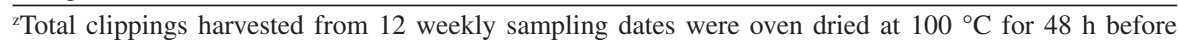
weighing.

${ }^{y}$ Roots were harvested from entire containers 12 weeks after initial treatments.

Data analyses were made using the analysis of variance with SAS general linear model procedure (SAS Institute, Cary, N.C.). Mean separations were made with Fishers protected LSD test at alpha $=0.05$ for visual ratings, chlorophyll concentrations, and clipping yield and alpha $=0.10$ for root mass and root length. Orthogonal polynomial contrasts examined linear and quadratic relationships between plant response and level of paclobutrazol. Study $\times$ treatment interactions did not occur for total clipping yield, root mass, root length, and chlorophyll concentrations; therefore, studies were combined.

\section{Results}

Turf quality, phytotoxicity, and chlorophyll concentrations. Color enhancements were not observed from paclobutrazol in Study 1 (Table 2). However, in Study 2, visual quality ratings were $13 \%$ higher than the control for all paclobutrazol rates, 2 weeks after initial treatments (WAIT) (Table 2). Phytotoxicity was observed with Rate 1; however, visual quality ratings were always greater or equal to untreated turf (Tables 2 and 3 ). Turf quality for Rate 2 was $24 \%$ and $15 \%$ lower than the control 12 WAIT in Studies 1 and 2 (Table 2). Unacceptable phytotoxicity was observed for Rates 2 and 3 on every observation date in Study 1 and from 4 to 10 WAIT in Study 2 (Table 3). Visual quality from Rate 3 was reduced $18 \% 4$ WAIT in Study 1 and remained consistently lower than untreated turf (Table 2). Chlorophyll concentrations were never significantly different from untreated turf and showed no relationship with paclobutrazol rates (data not shown).

Clipping yield. Clipping yield quadratically decreased with paclobutrazol rates (Table 4). Compared to untreated turf, clipping yield was reduced $65 \%, 84 \%$, and $92 \%$ by Rates 1,2 , and 3 , respectively.

Roots and thatch. Root mass and root length linearly decreased with paclobutrazol rates (Table 4). Root mass after 12 weeks was reduced $28 \%, 45 \%$, and $61 \%$ for turf treated with Rates 1, 2, and 3, respectively, compared to untreated turf. Bermudagrass root length was reduced $13 \%, 19 \%$, and $19 \%$ by Rates 1 , 2 , and 3, respectively (Table 4). Paclobutrazol treatments had no meaningful differences in bermudagrass thatch mass after 12 weeks (data not shown).

\section{Discussion}

Paclobutrazol is an effective PGR for suppressing vegetative growth of bermudagrass turf (Johnson, 1990, 1992). For creeping bentgrass putting greens, paclobutrazol effectively suppresses Poa annua and may be routinely applied at 0.14 and $0.28 \mathrm{~kg} \cdot \mathrm{ha}^{-1}$ without inhibiting root growth (Bell et al., 2004; Fagerness and Yelverton, 2001). Paclobutrazol may also be used for overseeded bermudagrass greens for turf enhancement and Poa annua control during winter and spring months (McCarty and Miller, 2002).

Paclobutrazol provided consistent growth suppression at $0.14,0.28$, and $0.42 \mathrm{~kg} \cdot \mathrm{ha}^{-1}$ per 6 weeks on a dwarf-type bermudagrass putting green cultivar, 'TifEagle'. However, visual quality was unacceptable for turf treated with 0.28 and $0.42 \mathrm{~kg} \cdot \mathrm{ha}^{-1}$ due to high phytotoxicity. Bermudagrass treated with $0.14 \mathrm{~kg} \cdot \mathrm{ha}^{-1}$ had noticeable discoloration but was not as severe as the other rates. Turf discoloration from initial applications does not endorse repeat application at any of these rates for 'TifEagle' bermudagrass. Furthermore, repeated applications of paclobutrazol reduced root growth at all three rates.

Since paclobutrazol provided exceptional shoot growth inhibition, future research should examine lower rates with different application regimens. Paclobutrazol may have the potential at very low rates for single applications only. Nevertheless, turf discoloration and negative rooting responses should advocate caution when using paclobutrazol on 'TifEagle' bermudagrass.

\section{Literature Cited}

Bai, S. and W. Chaney. 2001. Gibberellin synthesis inhibitors affect electron transport in plant mitochondria. Plant Growth Regulat. 35:257-262.

Bell, G., C. Stiegler, and K. Koh. 2004. Poa control: Perhaps there's hope. Golf Course Mgt. 72:123-126.

Buchanan, B.B., Gruissem, W., and R.L. Jones. 2000. Biochemistry and molecular biology of plants. Amer. Soc. Plant Physiol. Rockville, Md.

Fagerness, M.J. and F.H Yelverton. 2001. Plant growth regulator and mowing height effects on seasonal root growth of 'Penncross' creeping 
bentgrass. Crop Sci. 41:1901-1905.

Fletcher, R.A.,A. Gilley, T.D. Davis, and N. Sanklha. 2000. Triazoles as plant growth regulators and stress protectants. Hort. Rev. 24:55-138.

Fletcher, R.A., C.R. Sopher, and N.N. Vettakkorumakankav. 2000a. Regulation of gibberellins is crucial for plant stress protection, p. 71-87. In: A.S. Basra (ed.). Plant growth regulators in agriculture and horticulture: Their role and commercial uses. Marcel Dekker, Inc, New York.

Hedden, P. and G. V. Hoad. 1994. Growth regulators and crop productivity, p. 173-198. In: A.S. Basra (ed.). Mechanism of plant growth and improved productivity: Modern approaches. Marcel Dekker, Inc, New York.

Johnson, B.J. 1990. Response of bermudagrass (Cynodon spp.) cultivars to multiple plant growth regulator treatments. Weed Technol. 4:549-554.
Johnson, B.J. 1992. Response of 'Tifway' bermudagrass to rate and frequency of flurprimidol and paclobutrazol application. HortScience 27:230-232.

McCarty, L.B. and G.L. Miller. 2002. Managing bermudagrass turf: Selection, construction, cultural practices and pest management strategies. Sleeping Bear Press, Chelsea, Mich.

Moran, R. and D. Porath. 1980. Chlorophyll determination in intact tissues using N,N-dimethylforamide. Plant Physiol. 65:478-479.

Murphy, T.R., T. Whitwell, B. McCarty, and F.H Yelverton. 2001. Turfgrass plant growth regulators, p. 552-561. In: L.B. McCarty (ed.). Best golf course management practices. Prentice-Hall, Upper Saddle River, N.J.

SAS Institute. 1999. The SAS system for Windows. v. 8.2. SAS Inst., Cary, N.C.
Sponsel, V.M. 1995. The biosynthesis and metabolism of gibberellins in higher plants, p. 66-97. In: P.J. Davies (ed.). 1995. Plant hormones: Physiology, biochemistry, and molecular biology. 2nd ed. Kluwer Academic Publ., Dordrecht, The Netherlands.

U.S. Golf Association Green Section Staff. 1993. USGA recommendations for a method of putting green construction. 1993 Revision. USGA Green Section Record 31(2):1-3.

Watschke, T.L. M.G. Prinster, and J.M. Brenninger. 1992. Plant growth regulators and turfgrass management, p. 557-588. In: D.V. Waddington, R.N. Carrow, and R.C. Shearman (eds.). Turfgrass. Amer. Soc. Agron. Monogr. 32.

White, R.H. 1998. Performance and management of new dwarf bermudagrasses. 1998 Semiannual research progress report. Texas A\&M Agr. Expt. Sta. 